Copyright (C) 2018 by the Kalmyk Scientific Center of the Russian Academy of Sciences

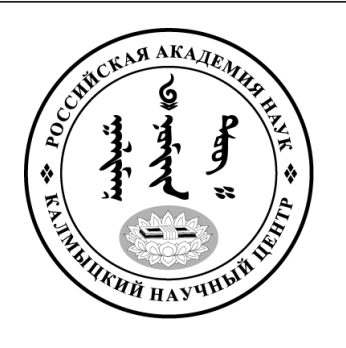

Published in the Russian Federation

Oriental Studies (Previous Name: Bulletin of the Kalmyk Institute for

Humanities of the Russian Academy of Sciences)

Has been issued as a journal since 2008

ISSN: 2619-0990; E-ISSN: 2619-1008

Vol. 39, Is. 5, pp. 27-47, 2018

DOI 10.22162/2619-0990-2018-39-5-27-47

Journal homepage: https://kigiran.elpub.ru

УДК 94(47).084.8

\title{
Жители Калмыкии - кавалеры «полководческих» орденов
}

Уташ Борисович Очиров $^{I}$

${ }^{1}$ доктор исторических наук, главный научный сотрудник, отдел истории, археологии и этнологии, Калмыцкий научный центр РАН (358000, Россия, г. Элиста, ул. им. И. К. Илишкина, д. 8). ORCID: 0000-0001-9957-5215. E-mail: ochirovub@kigiran.com

\section{Аннотация}

Введение. Статья посвящена анализу военных биографий жителей Калмыкии - кавалеров «полководческих» орденов. Под жителями Калмыкии в данной статье подразумеваются: уроженцы Калмыкии (которая берется в границах 1941 года), уроженцы других регионов, проживавшие к началу войны в Калмыкии и призванные оттуда в ряды Красной армии, уроженцы других регионов, проживавшие в Калмыкии после 1957 г. Под «полководческими» орденами в данной статье подразумеваются ордена Суворова, Кутузова, Богдана Хмельницкого и Александра Невского, которые вручались лицам высшего, старшего и среднего командного состава (спектр награждений орденом Богдана Хмельницкого был несколько шире) исключительно за полководческое мастерство. Эти ордена были учреждены в СССР в 1942-1943 гг., когда пришло осознание того, что полководческое мастерство командира для Красной армии более важно и значимо, нежели индивидуальная храбрость и политический фанатизм.

В период Великой Отечественной войны 35 жителей Калмыкии (в том числе пятеро дважды) были отмечены: четырьмя орденами Суворова, тремя орденами Кутузова, пятью орденами Богдана Хмельницкого и двадцатью восемью орденами Александра Невского. В статье приведены краткие военные биографии всех 35 кавалеров.

Цель: проанализировать военные биографии всех жителей Калмыкии - кавалеров «полководческих» орденов, выявить в них характерные черты, общее и особенное.

Memodbl. В ходе работы над статьей использовались как общенаучные (типологизация, анализ и синтез, индукция и дедукция, сравнение и аналогия), так и специальные исторические методы исследования (историко-генетический, историко-сравнительный, историко-типологический, историко-системный).

Pезультаты. Статистический анализ позволил выявить ряд особенностей этой группы военных командиров. Например, большинство изучаемых персоналий (28 из 35) являлись молодежью в возрасте от 16 до 29 лет (возраст приведен на начало войны), которая выросла и воспитывалась при Советской власти и была предана коммунистическим идеалам. Шестеро более старших командиров (в возрасте от 31 до 38 лет на начало войны) являлись людьми, которые осознанно связали свое будущее с Советской властью и готовы были отстаивать ее до самой смерти. Большинство изучаемых персоналий относятся к пехоте, при этом представители высокотехнологичных видов войск (флота, авиации, танковых, связи) среди них отсутствуют. Если же смотреть в разрезе по национальностям, то видно, что калмыки-кавалеры «полководческих» орденов составляют всего треть от общего числа. Это явно не коррелирует с тем, что калмыки, по данным всесоюзных переписей, составляли большинство в своем регионе. На 
этот фактор повлияли огульные и несправедливые обвинения калмыков в коллаборационизме и высылка всего калмыцкого народа в отдаленные районы страны.

Ключевые слова: Великая Отечественная война 1941-1945 гг., Калмыцкая АССР, Красная армия, орден Суворова, орден Кутузова, орден Богдана Хмельницкого, орден Александра Невского

Советская наградная система, совершенствовавшаяся вплоть до конца 1980-х гг., большей частью сформировалась еще в годы Великой Отечественной войны. Именно в этот период появились специальные награды для представителей определенных категорий, имеющих особые отличия: «солдатский» орден Славы, «маршальский» орден Победы, «полководческие» и «флотоводческие» ордена. Анализ различных групп награжденных, выделенных по одной из таких категорий, например, кавалеров «солдатского» или «полководческих» орденов, дает возможность оценить их вклад в Победу по отдельности, выявить какие-то обобщения или особенности. Результаты некоторых исследований по калмыкам-кавалерам определенного ордена были отражены автором в двух публикациях [Очиров 2016а; 2016б].

Новое исследование посвящено уже кавалерам не одного какого-то ордена, а целой категории орденов, отобранных по региональному принципу: статья посвящена кавалерам «полководческих» орденов жителям Калмыкии. В понятие «жители Калмыкии» включены следующие группы лиц:

- уроженцы Калмыкии (с учетом того, что Калмыкия как самостоятельный регион возникла в 1920 г., а ее границы неоднократно менялись вплоть до 1938 г., то в данную категорию внесены уроженцы населенных пунктов и территорий, входивших в состав Калмыцкой АССР к началу 1941 г.);

- уроженцы других регионов, проживавшие к началу войны в Калмыкии и призванные оттуда в ряды Красной армии;

- уроженцы других регионов, проживавшие в Калмыкии после ее восстановления в 1957 г.

«Полководческие» награды в СССР начали вводиться летом 1942 г., когда руководство Красной армии осознало, что существующая на тот момент палитра военных наград (Герой Советского Союза, ордена Ленина, Красного Знамени, Красной Звезды, медали «За отвагу», «За боевые заслуги») слишком бедна для того, чтобы по достоинству оценить все многообразие подвигов и заслуг, показанных нашими воинами, особенно полководческое мастерство, которое в условиях войны оказалось важнее, нежели индивидуальная храбрость и политический фанатизм. Поэтому в орденской системе страны были учреждены специальные награды, которые (в отличие от старых наград) могли получить только лица командно-начальствующего состава.

29 июля 1942 г. были учреждены ордена Суворова (трех степеней), Кутузова (сначала двух степеней, 8 февраля 1943 г. добавилась 3-я степень) и Александра Невского. 10 октября 1943 г. был учрежден орден Богдана Хмельницкого (трех степеней), а 8 ноября 1943 г. - орден Победы.

По старшинству полководческие награды (если не считать «маршальский» орден Победы) распределялись следующим образом: наиболее старшей наградой считался орден Суворова, затем шел орден Кутузова, затем - орден Богдана Хмельницкого, и самым «низшим» орденом являлся орден Александра Невского.

Разделение орденов Суворова и Кутузова на степени обуславливалось значением полководческого мастерства награждаемых военачальников в зависимости от занимаемых ими должностей: 1-й степенью награждались представители командного состава фронтового и армейского звена (командующие, их заместители, начальники штабов, начальники оперативных управлений и отделов, начальники родов войск), 2-й степенью - корпусного, дивизионного и бригадного звена (командиры, их заместители и начальники штабов), 3-й степенью полкового, батальонного звена (командиры полков и батальонов, начальники штаба полка), с февраля 1943 г. - также командиры рот [Сборник 1956: 256-259, 261].

Спектр награждений орденом Богдана Хмельницкого, учрежденного по предложению Н. С. Хрущева, А. П. Довженко и Н. П. Бажана, по статуту был заметно шире (эту награду могли получать партизаны, младший командный и рядовой состав), но награждение разными степенями так- 
же зависело от занимаемой должности. 1-й степенью награждались представители командного состава фронтового и армейского звена, а также командиры партизанских соединений, 2-й степенью - корпусного, дивизионного, бригадного и полкового звена, а также командиры партизанских соединений и отрядов, 3-й степенью - рядовой, сержантский, старшинский и офицерский состав до командира батальона и ему соответствующих включительно, командиры партизанских отрядов, командиры подразделений партизанских отрядов и партизаны [Сборник 1956: 262-263].

В некоторых случаях бывали исключения, например, особо отличившегося командира могли наградить более высокой степенью, чем полагалось по статуту. Например, командир батальона 181-й танковой бригады капитан М. И. Якушов, пленивший генерала А. А. Власова с группой офицеров РОА, был награжден орденом Суворова 2-й степ. [ЦАМО. Ф. 33. Оп. 686046. Д. 376. Л. 67-67об.].

В качестве другого примера можно назвать Героев Советского Союза, командиров 29-го гв. стрелкового корпуса гв. генерал-майора артиллерии Г. И. Хетагурова и 11-го гв. танкового корпуса гв. полковника А. Х. Бабаджаняна, представление которых на 2-ю «Золотую Звезду» за отличия при штурме Берлина отклонили, но в качестве своеобразной компенсации 29 мая 1945 г. наградили орденами Суворова 1-й степ. [ЦАМО. Ф. 33. Оп. 793756. Д. 51. Л. 139139об.; ОБД «Подвиг народа»]. Аналогичные замены имели место даже по отношению к командирам дивизионного звена. Например, по тому же Указу Президиума Верховного Совета СССР от 29 мая 1945 г. орденами Суворова 1-й степени вместо «Золотой Звезды» Героя Советского Союза наградили командиров 3-й, 14-й и 17-й гв. кавалерийских дивизий гв. генерал-майоров М. Д. Ягодина, Г. П. Коблова и П. Т. Курсакова [ОБД «Подвиг народа»].

Различия между орденами Суворова, Кутузова и Богдана Хмельницкого, согласно статутам, были не так уж велики и большей частью связаны с теми полководческими качествами, которые, по мнению разработчиков, прославленные военачальники проявили при жизни. Например, 2-ю степень ордена Суворова предполагалось давать: «За организацию боя по разгрому вражеского корпуса или дивизии, достиг- нутому с меньшими силами, в результате внезапной и решительной атаки...» (явный намек на победы, одержанные А. В. Суворовым в сражениях под Фокшанами и на Рымнике в 1789 г.); «За прорыв современной оборонительной полосы противника, развитие прорыва и организацию неотступного преследования...» (здесь можно провести параллели с форсированием Адды и прорывом позиций армии Б. Л. Шерера в начальной фазе Итальянского похода 1799 г.); «За организацию боя при нахождении в окружении численно превосходящих сил противника, выход из этого окружения и сохранение боеспособности своих частей...» (очевидная отсылка к Швейцарскому походу 1799 г.) и т. д. [Сборник 1956: 257].

1-ю степень ордена Кутузова согласно статуту должны были вручать «За хорошо разработанный и проведенный план вынужденного отхода крупных соединений, с организацией массированных контрударов, нанесения врагу тяжелых потерь и вывода своих на новые рубежи с малыми потерями... и полной боевой готовности» (очевидный намек на Тарутинский марш-маневр с серией арьергардных боев); «За умелую организацию операции крупных соединений по борьбе с превосходящими силами противника, изматывание его войск... и сохранение своих войск в постоянной готовности к решительному наступлению» (эта вычурно построенная фраза проводит явную параллель с отступлением русской армии в первый период кампании 1812 г.). Намек на полководческое искусство М. И. Кутузова в Отечественной войне 1812 года мы видим и в статуте 2-й степени, которую можно было получить «За исключительное упорство в противодействии наступлению превосходящих сил врага... с последующим переходом в решительное и успешное наступление» и т. д. [Сборник 1956: 258-259].

1-й степенью ордена Богдана Хмельницкого должны были награждать за «успешную, проведенную с применением умелого маневра операцию, в результате которой освобожден от врага район, город... боевую операцию, следствием которой явилось освобождение значительной части советской территории от врага» (очевидная отсылка к Национально-освободительной войне Б. Хмельницкого 1648-1654 гг.) [Сборник 1956: 262]. Разумеется, были и другие определения подвигов, за которые могли вручаться «полководческие» ордена - осов- 
ремененные и связанные с новыми родами войск, которых не было в XVIII-XIX вв. (танки и авиация).

Указанные определения были весьма расплывчаты и не исключали друг друга. Например, исключительное упорство в отражении атак противника с последующим переходом в наступление могло осуществляться путем прорыва оборонительной линии с последующим преследованием и разгромом врага меньшими силами с освобождением части советской территории, в том числе благодаря созданию превосходства сил на решающем участке «в трудной обстановке боя». Мало того, с изгнанием большей части сил врага за государственную границу СССР возникла проблема с «освобождением советской территории», тем не менее награждения орденами Богдана Хмельницкого осуществлялись и за подвиги, совершенные на территории Европы. Поэтому выбор ордена для награждения отличившегося полководца был в общем-то произвольным.

В результате, за одну и ту же операцию командующий объединением мог получить более престижный орден Суворова, а его заместитель или начальник штаба - более низкий по статусу орден Кутузова. Такие примеры мы можем увидеть с первых награждений (28 января 1943 г.): командующий Донским фронтом К. К. Рокоссовский был награжден орденом Суворова 1-й степени, а начальник его штаба М. С. Малинин орденом Кутузова 1-й степени. В некоторых случаях награждения орденом Суворова производились за успехи в наступлении, а орденом Кутузова - в обороне. Например, 27 августа 1943 г. по итогам операций «Румянцев», «Кутузов» и «Суворов» орденами Суворова 1-й степени были награждены командующий Степным фронтом И. С. Конев и командующий 53-й армией И. М. Манагаров (за освобождение Харькова), командующий Брянским фронтом М. М. Попов (за освобождение Орла), командующий 11-й гвардейской армией И. Х. Баграмян (за прорыв, сыгравший ключевую роль в успехе операции «Кутузов» и взятии Орла), а орденами Кутузова 1-й степени - командующий Воронежским фронтом Н. Ф. Ватутин и Центральным фронтом К. К. Рокоссовский, а также ряд их командармов (за отражение немецкого наступления на Курск). При этом командующий Западным фронтом В. Д. Соколовский, руководивший наступательной операцией «Суворов», хотя и освободил Смоленск, но действовал не так эффективно, как соседи, поэтому был отмечен за наступательную операцию более «низким» орденом Кутузова 1-й степени [ОБД «Подвиг народа»].

Следует отметить, что «полководческими» орденами, несмотря на статуты, награждали не только военачальников. Орденами Суворова и Кутузова награждались работники военно-промышленного комплекса, в том числе наркомы Б. Л. Ванников, В. А. Малышев, А. И. Шахурин, конструкторы авиационной и танковой техники, артиллерии и стрелкового вооружения, директора заводов, различные железнодорожные начальники, сотрудники органов госбезопасности и даже штатские лица (например, 3-й секретарь ЦК КП(б) Украины Д. С. Коротченко был награжден орденом Суворова 1-й степ.). Причем, такие награждения могли быть массовыми, как, например, 8 марта 1944 г., когда орденами Суворова и Кутузова 1 и 2-й степени были награждены 37 руководящих работников НКВД и НКГБ за участие в депортации карачаевцев, калмыков, чеченцев и ингушей [Ведомости 1944: 2].

Орден Александра Невского предназначался для офицеров «поля боя», только для командиров: от уровня взвода до уровня дивизии. Штабные работники, «колдующие» над картами в тыловых блиндажах, могли претендовать на другие «полководческие» ордена, но не на эту награду. Награждения орденом Александра Невского по статуту также предписывалось производить за полководческие успехи, похожие на битвы, выигранные прославленным русским военачальником средневековья. Например, за выбор «удачного момента для внезапного, смелого и стремительного нападения на врага и нанесение ему крупного поражения с малыми потерями для своих войск» (очевидный намек на Невскую битву) или за «четкую организацию взаимодействия родов войск и уничтожение полностью или большей части действующих превосходящих сил противника» (явная параллель с Ледовым побоищем) [Сборник 1956: 260].

Разумеется, помимо указанных оснований, были и другие, связанные с руководством подразделениями более современных родов войск: артиллерии, танков, авиации, саперов, связистов и десантников [Сборник 1956: 260]. 
В более ранний период доступ к наградной документации, которая хранилась в основном в архивах, был в определенной степени ограничен, к тому же отсутствовала возможность автоматического поиска различных категорий награжденных (имеющих ту или иную награду, призванных из того или иного региона и т. д.). Относительно полные базы данных имелись лишь по Героям Советского Союза и полным кавалерам орденов Славы (которые позже были опубликованы [Герои... 1987; 1988; Кавалеры... 2000б]), что позволило сделать некоторые выводы по этим категориям наград.

Например, в 1968 г. (перед празднованием 50-летия Советской армии) министерство обороны СССР опубликовало в «Красной Звезде» статистику о Героях Советского Союза, награжденных за подвиги в период Великой Отечественной войны (включая послевоенные награждения по 1968 г.), в разрезе по национальностям и в соотношении с численностью населения по переписи 1959 г. В этом своеобразном рейтинге на 1-м месте оказались осетины, на 2-м месте - калмыки, на 3-м - адыгейцы, на 4-м - абхазы, на 5-м - русские, на 6-м - украинцы, на 7-м - мордовцы и карелы, на 8-м - кабардинцы, на 9-м - башкиры, на 10-м - белорусы и т. д. [Красная звезда. 1968. 22 февраля]. Если же мы пересчитаем эти же показатели по данным более ранней переписи - 1939 г. [Всесоюзная перепись... 1992], то увидим немного иной порядок расположения национальностей: 1) осетины; 2) русские; 3) украинцы; 4) адыгейцы; 5) абхазы; 6) калмыки; 7) белорусы; 8) кабардинцы; 9) башкиры; 10) мордовцы.

Перемещение калмыков с 6-го места (по переписи 1939 г.) на 2-е (по переписи 1959 г.) объясняется чудовищными демографическими потерями (почти треть населения) в период депортации, от которых калмыки к 1959 г. так и не оправились, в то время, как численность большинства перечисленных народов (за исключением адыгейцев, мордовцев и карелов) к указанному году превысила довоенные цифры. Столь значительное сокращение делимого при сохранении цифры делителя привело к заметному увеличению результата. Аналогичное перемещение мордовцев с 10-го на 7-е место также связано с сокращением их численности в период с 1939 г. по 1959 г. более чем на 170 тыс. человек в результате ассимиляционных процессов. Заметное падение аналогичных показателей по переписи 1959 г. у украинцев и белорусов объясняется присоединением большого количества одноплеменников в сентябре 1939 г., которые в переписи, проходившей за восемь месяцев до этого, разумеется, не учитывались (то есть в расчетах по переписи 1959 г. произошло увеличение делимого). Появление же карел в списке топ-10, по данным переписи 1959 г., объясняется значительным сокращением их численности в послевоенные годы в результате эмиграции в Финляндию.

В начале XXI века ситуация кардинально изменилась. По заказу министерства обороны РФ корпорация «ЭЛАР» осуществила титанический проект по сканированию гигантского фонда наградных документов Центрального архива министерства обороны РФ (далее - ЦАМО), электронные копии которых были выложены на специальном сайте - ОБД «Подвиг народа» [ОБД «Подвиг народа»]. Появление столь огромного массива информации, находящейся в открытом доступе, предоставило широкое поле для новых исследований в этом направлении.

Многолетний поиск сведений в указанной базе данных, литературе, средствах массовой информации, архивах (в том числе и с карточками награжденных в ЦАМО) позволил выявить 35 кавалеров «полководческих» орденов, которых можно считать жителями Калмыкии. Четверо из них были кавалерами ордена Суворова (двое - 2-й степени, двое - 3-й), из которых трое стали также кавалерами ордена Кутузова (один - 1-й степени, один - 2-й степ., один - 3-й степ.), пятеро - кавалерами ордена Богдана Хмельницкого 3-й степ. (один из них также являлся кавалером ордена Александра Невского), еще 27 человек - кавалерами ордена Александра Невского (один из них был награжден этим орденом дважды).

Для сведения приведем краткие военные биографии всех 35 кавалеров «полководческих» орденов, выстроив их по алфавиту.

Андрюшкеев Убуш Доржиевич (19121979). Калмык.

Уроженец хотона Эмгдюд Яндыко-Мочажного улуса Калмыцкой степи. После окончания школы работал учителем, а в 19 лет стал заведующим начальной школы. В 1938 г. принят на работу в НКВД, откуда его направили секретарем-переводчиком в 
Управление госбезопасности МВД Монголии. Участник боев на Халхин-Голе. В августе 1941 г. вернулся в СССР [Годаев 2005: 85-86].

10 декабря 1941 г. добровольно явился в Лаганский РВК Калмыцкой АССР для зачисления в ряды калмыцкой национальной дивизии. Был назначен командиром отделения батареи 273-го кавалерийского полка 110-й Калмыцкой кавалерийской дивизии [Солдаты Победы 2015: 34-35]. 20 мая 1942 г., незадолго до вступления национальной кавдивизии в бой, его направили на курсы минометчиков. После окончания курсов сержант У. Д. Андрюшкеев был назначен командиром минометного расчета, а затем - зам. политрука минометной роты 605-го стрелкового полка 135-й стрелковой дивизии 13-й армии Брянского фронта.

Участник войны с 6 июля 1942 г. на Брянском фронте.

1 декабря 1942 г. как бывшего сотрудника НКВД его направили на курсы оперативных работников. После их окончания был произведен в офицеры и назначен следователем Особого отдела 48-й армии, затем оперативником отдела контрразведки 2-й танковой армии [Годаев 2005: 86]. Воевал на Брянском, Центральном, Белорусском фронтах. В начале 1944 г. по национальному признаку был отчислен из органов военной контрразведки в резерв офицерского состава. Однако У. Д. Андрюшкеев добился направления на курсы младших лейтенантов 48-й армии, по окончании которых 8 апреля 1944 г. был назначен командиром взвода 471-го стрелкового полка 73-й стрелковой дивизии 29-го стрелкового корпуса 48-й армии Белорусского фронта, 16 апреля переименованного в 1-й Белорусский (с 21 сентября 1944 г. 48-я армия перешла в состав 2-го Белорусского, с 11 февраля 1945 г. 3-го Белорусского фронта). Участвовал в боях на территории Белоруссии, Польши и Восточной Пруссии. Награжден орденами Красной Звезды и Александра Невского (приказ № 799/н 48-й армии от 12 апреля 1945 г.) [ЦАМО. Ф. 33. Оп. 686196. Д. 2807. Л. 216-216об.].

После демобилизации в 1946 г. был направлен на спецпоселение в Новосибирскую область, затем жил на Сахалине [Годаев 2005: 86-87]. После возвращения в Калмыкию проживал в Элисте.

Базюк Иван Кириллович (1921-1985). Русский.
Уроженец с. Яшалта Большедербетовского улуса (ныне с. Соленое Яшалтинского района) Калмыцкой автономной области.

Призван в 1939 г. Западным РВК Калмыцкой АССР. Направлен в Астраханское пехотное училище, из которого был выпущен лейтенантом в июне 1941 г. Уже после начала войны получил назначение в Орловский военный округ, в 873-й стрелковый полк 276-й стрелковой дивизии, которая убыла в Крым.

Участник войны с августа 1941 г. в Крыму. Воевал в 51-й армии, на Крымском, Южном фронтах. Трижды ранен. Осенью 1942 г. служил в штабе 248-й стрелковой дивизии 28-й армии и принимал участие в освобождении территории Калмыкии. К концу 1943 г. он был уже командиром батальона 1173-го стрелкового полка 347-й стрелковой дивизии 37-го стрелкового корпуса 3-й гв. армии 4-го Украинского фронта. За отличия в боях награжден орденами Суворова 3-й степени (приказ № 45/н 4-го Украинского фронта от 25 декабря 1943 г.) и Отечественной войны 1-й степени.

Любопытно отметить, что первоначально Ивана Кирилловича представляли к званию Героя Советского Союза, однако комкор счел нужным «понизить» награду до ордена Ленина, а командарм Д. Д. Лелюшенко - до ордена Суворова 3-й степени, с чем командующий 4-м Украинским фронтом Ф. И. Толбухин согласился [ЦАМО. Ф. 33. Оп. 686044. Д. 1405. Л. 26-26об.].

После демобилизации жил в с. Соленое Яшалтинского района Калмыцкой АССР.

Бевеликов Николай Даржинович (1909-1961). Калмык.

Уроженец 1-го Ики-Чоносовского аймака Большедербетовского улуса Ставропольской губернии. После окончания школы крестьянской молодежи работал в колхозе.

Призван в 1941 г. Западным РВК Калмыцкой АССР.

Участник войны с 1941 г. на Южном фронте, был ранен.

В течение шести месяцев 1943 г. в составе 62-го отд. батальона ПТР 3-й гв. армии Юго-Западного фронта многократно отличился в боях на Северском Донце. В феврале на поле боя был произведен в младшие лейтенанты и назначен командиром взвода ПТР. Награжден медалью «За отвагу», орденами Александра Невского (приказ № 97/н 3-й гв. армии от 31 июля 1943 г.) 
[ЦАМО. Ф. 33. Оп. 682526. Д. 1523. Л. 98 98об.] и Красного Знамени [ЦАМО. Ф. 33. Оп. 686044. Д. 484. Л. 126-126об.]. Тяжело ранен, бойцам с большим трудом, но все же удалось переправить раненого командира через Донец [Каруева 2010].

После демобилизации в 1946 г. был направлен на спецпоселение в Омскую область. После возвращения из депортации жил в Яшалтинском районе Калмыцкой АССР [Беляков, Надышев 2009].

Белькеев Убуш Цеденович (19241986). Калмык.

Уроженец хотона Бичкин-Шоха Яндыко-Мочажного улуса Калмыцкой степи. Окончил 7-летнюю школу.

Призван в 1942 г. Долбанским РВК Калмыцкой АССР и направлен в военное училище, из которого был выпущен младшим лейтенантом.

Участник войны с февраля 1943 г. на Северо-Кавказском фронте. Трижды ранен.

С лета 1943 г. У. Ц. Белькеев командовал взводом 66-го стрелкового полка 61-й стрелковой дивизии, с которым воевал на Тамани, на Южной Украине, Белоруссии и Восточной Пруссии (10 октября 1944 г. 61-ю дивизию вместе с 28-й армией включили в состав 3-го Белорусского фронта). Награжден орденом Александра Невского (приказ № 15/н 28-й армии от 27 марта 1945 г.) [ЦАМО. Ф. 33. Оп. 686196. Д. 5889. Л. 353-353об.].

После демобилизации был направлен на спецпоселение в Тюменской области. После возвращения из депортации жил в с. Караванное Лиманского (бывшего Долбанского) района Астраханской области [Балакаева 2013: 4].

Брыков Иван Федорович (1919-??). Русский.

Призван Долбанским РВК Калмыцкой АССР в мае 1942 г.

Участник войны с октября 1942 г. по январь 1943 г. на Юго-Западном фронте. Ранен под Чертково. Окончил пехотное училище.

Был назначен командиром взвода 172го гв. стрелкового полка 57-й гв. стрелковой дивизии 4-го гв. стрелкового корпуса 8-й гв. армии 1-го Белорусского фронта. За отличия в боях награжден орденами Красной Звезды и Богдана Хмельницкого 3-й степ. (приказ № 384/н 1-го Белорусского фронта от 7 декабря 1944 г.) [ЦАМО. Ф. 33. Оп. 690155. Д. 5447. Л. 193-193об.].

\section{Бутцинов Александр Бадмаевич} (1921-1945). Калмык.

Уроженец с. Кердата Большедербетовского улуса Ставропольской губернии, сын зайсанга Эренцена Польтеева, раскулаченного и расстрелянного в 1929 г. Вдова, узнав о смерти мужа, решила уехать с детьми не к месту ссылки, а в соседний регион. Когда она вышла замуж повторно, то сменила фамилию и выправила детям документы с фамилией и отчеством отчима, после чего рискнула вернуться в Калмыкию.

17 июля 1941 г. А. Б. Бутцинов, только что закончивший 10-й класс, не дожидаясь призыва, добровольцем явился в Элистинский ГВК Калмыцкой АССР, и был направлен в Ростовское пехотное училище [ПМА: С. Э. Пальтеева].

Участник войны с сентября 1941 г., еще будучи курсантом училища. Трижды ранен.

Воевал на Дону, на Тамани, на Украине. Произведен в старшие лейтенанты, назначен командиром стрелковой роты 606-го стрелкового полка 317-й стрелковой дивизии 22-го стрелкового корпуса 18-й армии 1-го Украинского фронта. Многократно отличился в боях на Правобережной Украине, продемонстрировав блестящие полководческие дарования. Дважды представлялся к орденам Красного Знамени, но оба представления были «понижены» до орденов Александра Невского (приказ № 35/н 18-й армии от 16 февраля 1944 г.) и Красной Звезды [ЦАМО. Ф. 33. Оп. 690155. Д. 1307. Л. 322-322об.].

Весной 1944 г. А. Б. Бутцинова сняли с фронта по национальному признаку и отправили в Новосибирск (Сибирский военный округ) [ПМА: С. Э. Пальтеева]. Однако А. Б. Бутцинов не желал отсиживаться в тылу и добился возвращения на фронт, но в родную 317-ю дивизию, перешедшую к тому времени в состав 4-го Украинского фронта, попасть не удалось. Он стал командиром роты автоматчиков 318-го стрелкового полка 241-й стрелковой дивизии 52-го стрелкового корпуса 38-й армии 4-го Украинского фронта.

Капитан А. Б. Бутцинов был убит 9 февраля 1945 г. и похоронен в старой части г. Бельско-Бяла, в 200 метрах южнее костела [ОБД «Мемориал»]. Позже его прах перезахоронили в братской могиле № 12 кладбища Армии Червоной.

Воронин Михаил Максимович (1914??). Русский. 
Уроженец с. Промысловка Астраханского уезда Астраханской губернии (к 1941 г. это село входило в состав Долбанского улуса Калмыцкой АССР).

Призван Долбанским РВК Калмыцкой АССР в 1937 г.

Участник войны с 1941 г. Трижды ранен. Воевал на Западном, Брянском, Центральном, Воронежском, 1-м Украинском и Белорусском фронтах. Командир пулеметного взвода 182-го армейского заградотряда 13-й армии 1-го Украинского фронта и пулеметной роты 514-го стрелкового полка 172-й стрелковой дивизии 102-го стрелкового корпуса 1-го Украинского фронта. За многократные отличия награжден орденами Красной Звезды, Александра Невского (приказ № 216/н 13-й армии от 8 сентября 1944 г.) [ЦАМО. Ф. 33. Оп. 690155. Д. 3059. Л. 25-25об.] и Отечественной войны 1-й степени.

Воронцов Виктор Иванович (19232003). Русский.

Уроженец станицы Рождественской Лабинского отдела Кубанской области (с 1924 г. - Ново-Александровского района Ставропольской губернии). Позднее с семьей переехал в Элисту, здесь окончил школу.

Призван Элистинским ГВК Калмыцкой ACCP в 1942 г. и направлен в Астраханское пехотное училище.

Участник войны с августа 1942 г., когда училище преобразовали в 899-й стрелковый полк 248-й стрелковой дивизии. Воевал на территории Калмыкии в составе отряда капитана А. Постного, был ранен при штурме Яшкуля. Затем сражался на Южном, 4-м Украинском и 1-м Прибалтийском фронтах под Ростовом, Мелитополем, в Крыму и Прибалтике. Командир стрелкового взвода 3-го батальона 943-го стрелкового полка 257-й стрелковой дивизии 10-го стрелкового корпуса, затем адъютант штаба моторизованного батальона автоматчиков 202-й танковой бригады 19-го танкового корпуса. Награжден орденами Александра Невского (приказ № 21/н 51-й армии от 30 апреля 1944 г.) [ЦАМО. Ф. 33. Оп. 690155. Д. 1814. Л. 16-16об.] и Красной Звезды. Всего ранен 4 раза, после 4-го ранения лишился ноги и в 21 год стал инвалидом 2-й группы [Князев 1975: 180-181].

После демобилизации жил в г. Элисте.

Горлов Андрей Яковлевич (1908-?). Русский.
Уроженец с. Каменный Яр Черноярского уезда Астраханской губернии. Позднее с семьей переехал в Малые Дербеты.

Призван Малодербетовским РВК Калмыцкой АССР в конце 1941 г. и направлен в 311-й кавалерийский полк 110-й Калмыцкой кавалерийской дивизии. Летом 1942 г. попал в плен, но в начале 1943 г. был освобожден и направлен в 1374-й стрелковый полк 416-й стрелковой дивизии 44-й армии Южного фронта [ОБД «Мемориал»]. Сражался на «Миус-фронте» и северной Таврии. Отличился в бою на Кальмиусе (награжден медалью «За боевые заслуги»). За подвиги при форсировании р. Молочной был представлен к званию Героя Советского Союза, но начдив «понизил» награду до ордена Богдана Хмельницкого 3-й степ., а командующий 28-й армией В. Ф. Герасименко утвердил это решение [ЦАМО. Ф. 33. Оп. 686044. Д. 1063. Л. 213-213об.].

После демобилизации жил в с. Каменный Яр.

Городовиков Басан Бадьминович (1910-1983). Калмык.

Уроженец хутора Мокрая Эльмута Платовской станицы Сальского округа.

В 1927 г. поступил в кавалерийскую школу горских национальностей (Краснодар) и окончил ее в 1930 г., после чего был назначен командиром взвода, затем - Калмыцкого эскадрона 5-й кавалерийской дивизии имени М. Ф. Блинова. Окончил Военную академию им. Фрунзе и Военно-воздушную академию командного и штурманского состава. После начала войны подполковник Б. Б. Городовиков стал командиром вновь сформированного 71-го кавалерийского полка 48-й кавалерийской дивизии, которая вскоре отправилась в Крым, в состав 51-й армии.

Участник войны с 19 октября 1941 г. в Крыму. В ноябре отступающие части 48-й кавдивизии оказались отрезаны от главных сил и перешли к партизанской борьбе. Б. Б. Городовиков стал командиром 3-го «красноармейского» партизанского отряда, a c 1 мая 1942 г. - командующим 1-го партизанского района Крыма. В апреле 1942 г. он был награжден орденом Красного Знамени, произведен в полковники, а 16 июня эвакуирован самолетом на «большую землю».

После этого Б. Б. Городовиков командовал 251-й, 85-й гв., 184-й и 63-й стрелковыми дивизиями, с которыми сражался на Западном, 3-м Белорусском, 1-м Дальневосточном фронтах, в том числе в ходе та- 
ких крупных стратегических операций, как «Марс», «Суворов», «Багратион». При этом молодой военачальник продемонстрировал блестящие полководческие дарования вкупе с беспримерным личным мужеством и отвагой. За многократные отличия ему было присвоено звание Героя Советского Союза, его наградили орденами Ленина, тремя орденами Красного Знамени, орденами Кутузова 2-й степ. [ЦАМО. Ф. 33. Оп. 682525. Д. 47. Л. 196-196об.], Суворова 2-й степ. [ЦАМО. Ф. 33. Оп. 686196. Д. 7745. Л. 6565об.], Красной Звезды (за выслугу лет), произвели в генерал-майоры.

Любопытно, что в конце 1944 г. - начале 1945 г. при награждении третьим орденом Красного Знамени Б. Б. Городовикова первоначально представили к ордену Суворова 2-й степени, но командарм-5 генерал-полковник Н. И. Крылов (тот самый, который осенью 1945 г. «понизит» представление Э. Л. Бадмаева к званию Героя Советского Союза до ордена Ленина) заменил эту награду на орден Красного Знамени.

После войны служил в Вооруженных силах СССР до 1960 г. Решением Секретариата ЦК КПСС был уволен в запас в звании генерал-лейтенанта и направлен в Калмыкию для руководящей работы. В 1960-1978 гг. работал в Калмыкии вторым, затем первым (с 1961 г.) секретарем Калмыцкого обкома КПСС, где показал себя выдающимся и талантливым управленцем, оставившим о себе в народе добрую память [Балакаев 1995]. После отставки жил в г. Москве.

Дедов Василий Иванович (1912-1976). Русский.

Уроженец с. Промысловка Астраханского уезда Астраханской губернии (к 1941 г. это село входило в состав Долбанского улуса Калмыцкой АССР).

Призван в 1941 г. Элистинским ГВК Калмыцкой АССР.

Участник войны с августа 1941 г. на Юго-Западном фронте, 1 октября легко ранен под Днепропетровском, остался в строю.

В 1942 г. направлен в артиллерийское училище.

В 1944-1945 гг. воевал на 1-м Прибалтийском и 1-м Белорусском фронтах. Командир огневого взвода 1174-го истребительно-противотанкового артиллерийского полка 39-й отд. истребительно-противотанковой артиллерийской бригады РГК. Награжден орденами Красной Звезды, Алек- сандра Невского (приказ № 0179 командующего артиллерией 1-го Белорусского фронта от 7 апреля 1945 г.) [ЦАМО. Ф. 33. Оп. 686196. Д. 6146. Л. 45-45об.]. Участник штурма Берлина.

После демобилизации жил в Астраханской области.

Донской Владимир Васильевич (1922-??). Русский.

Уроженец с. Михайловка Астраханского уезда Астраханской губернии (к 1941 г. село входило в состав Долбанского улуса Калмыцкой АССР).

Призван 22 июня 1941 г. Долбанским РВК Калмыцкой АССР и направлен в Ростовское артиллерийское училище, ускоренный курс которого окончил в том же году.

Участник войны с 1941 г. на Северо-Западном, Калининском, 2-м Прибалтийском фронтах, с 25 марта 1944 г. — на 1-м Белорусском фронте. Командир батареи 45-мм орудий 1319-го стрелкового полка 185-й стрелковой дивизии. Был награжден орденами Красной Звезды, Александра Невского (приказ № 12/н командующего артиллерией 47-й армии от 18 февраля 1945 г.) [ЦАМО. Ф. 33. Оп. 686196. Д. 2605. Л. 29-29об.], Отечественной войны 2-й степени.

После окончания войны остался служить в армии, и был уволен в запас в 1968 г. в звании подполковника. После демобилизации проживал в Московской области [Кавалеры... 2000: 161].

Жуков Василий Андреевич (1925-??). Русский.

Уроженец с. Уманцево Малодербетовского улуса Калмыцкой автономной области (с 1930 г. это село включено в состав Сарпинского улуса).

Призван Сарпинским РВК Калмыцкой АССР в декабре 1942 г.

Воевал с марта 1943 г. по январь 1944 г. на Южном фронте.

С мая 1944 г. - 2-й Белорусский фронт. Четырежды ранен. Сначала служил телефонистом 664-го артиллерийского полка 129-й стрелковой дивизии, затем стал командиром пулеметного расчета 32-го гв. стрелкового полка 12-й гв. стрелковой дивизии 9-го гв. стрелкового корпуса 61-й армии 1-го Белорусского фронта. За свои отличия награжден орденами Красной Звезды и Богдана Хмельницкого 3-й степ. (приказ № 602 1-го Белорусского фронта от 30 мая 1945 г.) [ЦАМО. Ф. 33. Оп. 686196. Д. 4167. Л. 37-37об.]. 
После демобилизации жил в с. УманцеBо.

Игнатов Михаил Митрофанович (1920-??). Русский.

Уроженец д. Никоново Сасовского уезда Рязанской губернии (в 1941 г. эта деревня входила в состав Чучковского района Рязанской области).

Призван Малодербетовским РВК Калмыцкой АССР в 1940 г.

Участник войны с 24 июня 1941 г. Зенитчик, ефрейтор. Служил наводчиком зенитного орудия 161-го отд. зенитно-артиллерийского дивизиона 17-й стрелковой дивизии 43-й армии Западного фронта. Участник Битвы за Москву. В марте 1942 г. награжден орденом Красной Звезды за два бомбардировщика, сбитых 18 января и 20 февраля.

С 1943 г. - командир орудия 131-го зенитно-артиллерийского полка 1-го гв. кавалерийского корпуса, старший сержант. Награжден медалью «За отвагу» и орденом Богдана Хмельницкого 3-й степ. (приказ № 130/н 1-го Украинского фронта от 20 сентября 1944 г.) [ЦАМО. Ф. 33. Оп. 690155. Д. 1620. Л. 89-89об.].

После демобилизации вернулся на родину и жил в дер. Никоново Чучковского района Рязанской области.

Инчиков Александр Сергеевич (1923??). Русский.

Уроженец с. Михайловка Астраханского уезда Астраханской губернии (к 1941 г. село входило в состав Долбанского улуса Калмыцкой АССР).

Призван Долбанским РВК Калмыцкой АССР в июне 1941 г.

Воевал на Южном фронте в октябре-ноябре 1941 г. Затем был направлен в артиллерийское училище, по окончании которого получил назначение на Воронежский фронт (с мая 1943 г.), в 222-й истребительно-противотанковый артиллерийский полк. Занимал должности командира 3-й батареи и пом. начальника штаба полка. Многократно отличился в боях в составе Воронежского, 1 и 2-го Украинских фронтов. Награжден орденами Александра Невского (приказ № 030/н командующего артиллерией 38-й армии от 24 ноября 1943 г.), Отечественной войны 1-й степени, Красного Знамени, Отечественной войны 2-й степени [ЦАМО. Ф. 33. Оп. 690306. Д. 941. Л. 164-164об.].

Лопатин Анатолий Алексеевич (19201945). Русский.
Уроженец с. Чилгир Икицохуровского улуса Калмыцкой степи. Позже вместе с семьей переехал в с. Лагань Калмыцкой автономной области, там окончил школу. Поступил в Буденновский железнодорожный техникум.

В декабре 1939 г. призван Буденновским РВК Орджоникидзевского (Ставропольского) края.

Участник войны на Юго-Западном фронте с июля 1941 г. В ходе войны А. А. Лопатин окончил военное училище (1941 г.), курсы «Выстрел» (1942 г.), курсы усовершенствования офицерского состава (1943 г.). Трижды ранен. После первых боев сделал стремительную карьеру и уже в начале 1943 г. командовал батальоном, а после развертывания 118-й стрелковой дивизии на базе 152-й стрелковой бригады был назначен зам. командира 463-го стрелкового полка. Многократно отличился на ЮгоЗападном, Западном, Южном, 4, 3 и 1-м Украинских фронтах. Награжден орденами Отечественной войны 2-й степени, Александра Невского (приказ № 58/н 57-й армии от 29 апреля 1944 г.), вторым орденом Александра Невского (приказ № 51/н 5-й гв. армии от 18 сентября 1944 г.) [ЦАМО. Ф. 33. Оп. 690155. Д. 5104. Л. 102-102об.].

В 1945 г. майор А. А. Лопатина был назначен командиром 463-го стрелкового полка. В апреле 1945 г. 463-й полк, действуя как десант 4-го гв. танкового корпуса, прорвался в тыл противника и нанес ему значительные потери. 22 апреля 1945 г. майор А. А. Лопатин погиб в бою. Похоронен в г. Аннабург (Германия). Посмертно присвоено звание Героя Советского Союза, и награжден орденом Ленина [ЦАМО. Ф. 33. Оп. 793756. Д. 28. Л. 143-143об.].

Май-Ленский Петр Емельянович (1913-??). Русский.

Уроженец с Дербетовка Медвеженского уезда Ставропольской губернии (с 1924 г. село входит в состав Винодельненского района Северо-Кавказского края, ныне Ипатовского района Ставропольского края).

Призван в 1931 г. Элистинским ГВК Калмыцкой АССР. Окончил пехотное училище.

Участник войны с июня 1942 г. Трижды ранен. Воевал на Северо-Кавказском, Южном, 2 и 3-м Украинских фронтах. С ноября 1944 г. гв. майор П. Е. Май-Ленский командует стрелковым батальоном 119-го гв. стрелкового полка 40-й гв. стрелковой 
дивизии 4-й гв. армии. Награжден орденами Отечественной войны 1-й степ. и Александра Невского (приказ № 54/н 4-й гв. армии от 23 июня 1945 г.) [ЦАМО. Ф. 33. Оп. 690306. Д. 2466. Л. 256-256об.], а также медалью «За боевые заслуги» (за выслугу 10 лет).

Манджиев Тимофей Петрович (19121977). Калмык.

Уроженец хутора Киреев Чернышевской станицы 2-го Донского округа Области Войска Донского (ныне Обливского района Ростовской области).

Призван в 1940 г. Саратовским ГВК.

Участник боевых действий с июля 1941 г. на Ленинградском фронте. Дважды ранен.

Сражался на Пулковских высотах и Ораниенбаумском плацдарме. Присвоено звание лейтенанта. Назначен командиром роты 295-го Ропшинского инженерного батальона 2-й ударной армии Ленинградского фронта. В начале 1944 г. лейтенант Т. П. Манджиев участвовал в операции по окончательному снятию блокады Ленинграда [Илишкин 2003], в боях на ауверском плацдарме под Нарвой (в западной историографии больше известных как битва «североевропейских СС»). 6 июня 1944 г. 295-й саперный батальон был переформирован в 173-й инженерно-саперный батальон, а в июле вошел в состав 21-й инженерно-саперной бригады. Т. П. Манджиев многократно отличился в боях под Нарвой, на территории Эстонии, Польши, Германии, был повышен в звании до капитана, награжден орденами Красной Звезды, Отечественной войны 2-й степени, Александра Невского (приказ № 68/н 2-й ударной армии от 16 мая 1945 г.) [ЦАМО. Ф. 33. Оп. 687572. Д. 1280. Л. 88-88об.].

После демобилизации в 1946 г. был направлен на спецпоселение в Сибирь. После возвращения из депортации жил в с. Шарнут Сарпинского района Калмыцкой АССР.

Надиев Дорджи Яковлевич (19222011). Калмык.

Уроженец Бага-Чоносовского аймака Манычского улуса. Окончил 10-летнюю школу в с. Приютное.

Призван в 1941 г. Приютненским РВК и направлен в Сумское артиллерийское училище, где был назначен зам. политрука [Надиев 2003: 40].

Участник боевых действий на Юго-Западном фронте с июля 1941 г. в составе курсантского отряда особого назначения. 16 августа 1941 г. ранен и вернулся в училище.

Выпущен лейтенантом и в апреле 1942 г. прибыл на службу в 890-й артиллерийский полк 330-й стрелковой дивизии, в составе которого прошел славный боевой путь от реки Болва до Эльбы. Служил адъютантом командира полка, зам. командира батареи, командиром 2-й батареи, зам. командира 1-го дивизиона, командиром 3-го дивизиона. Награжден медалью «За отвагу», орденом Красной Звезды, двумя орденами Отечественной войны 2-й степени, орденами Отечественной войны 1-й степени и Александра Невского (приказ № 056 командующего артиллерией 49-й армии от 31 мая 1945 г.) [ЦАМО. Ф. 33. Оп. 686196. Д. 6476. Л. 297-297об.].

Следует отметить, что 4 последних представления периода войны изначально подавались на более высокие награды. Например, при награждении 3-м орденом в августе 1944 г. командующий артиллерией 330-й дивизии полковник В. Шеремет и командир 330-й дивизии полковник В. А. Гусев предлагали наградить нашего земляка орденом Александра Невского, но командующий 50-й армией генерал-полковник И. В. Болдин «понизил» награду до ордена Отечественной войны 2-й степени (приказ № 0451 50-й армии от 24 августа 1944 г.) [ЦАМО. Ф. 33. Оп. 690155. Д. 3574. Л. 61-61 об.]. При награждении 4-м орденом начдив-330 В. А. Гусев, уже произведенный в генерал-майоры, «понизил» предлагаемый орден Красного Знамени на орден Кутузова 3-й степени (командир 47-го стрелкового корпуса генерал-лейтенант М. И. Дратвин согласился с ним), но начальник артиллерии 70-й армии генерал-лейтенант И. С. Бескин «понизил» награду до ордена Отечественной войны 1-й степени (приказ № 012/н от 23 марта 1945 г.) [ЦАМО. Ф. 33. Оп. 686196. Д. 6855. Л. 174-174об.]. При награждении 5-м орденом предложение об ордене Красного Знамени успешно прошло все инстанции (его поддержали В. Шеремет, В. А. Гусев и командование нового 70-го стрелкового корпуса, в состав которого вошла 330-я дивизия), но командующий артиллерией 49-й армии генерал-майор И. А. Разинцев «понизил» награду до ордена Александра Невского [ЦАМО. Ф. 33. Оп. 686196. Д. 6476. Л. 297-297об.]. 
Как видно, командование полка и дивизии довольно высоко оценивали выдающиеся подвиги Д. Я. Надиева, которого хорошо знали в своем соединении и считали отличным боевым офицером и ветераном части. «Понижения» наград происходили всегда на уровне армий, в составе которых воевала 330-я дивизия. Стала ли причиной постоянного «понижения» наград национальность? Об этом судить трудно (сам Дорджи Яковлевич в своих воспоминаниях об этом ничего никогда не говорил), но если учесть, что это происходило постоянно в 1944-1945 гг., то вероятность такой версии довольно высокая.

После демобилизации в 1948 г. Д. Я. Надиев уехал в Москву, где начал работать в одном из союзных министерств, в котором проработал 42 года, в том числе 22 - начальником Главного управления. В 1994 г. в возрасте 72 лет ушел на пенсию. За свои трудовые подвиги был награжден еще 4 орденами [Надиев 2003]. Таким образом, вместе с «юбилейным» орденом Отечественной войны (1985 г.) в его планке наград значится 10 орденов и 18 медалей.

Найденов Павел Иванович (1916-??). Русский.

Призван в 1941 г. Элистинским ГВК Калмыцкой АССР. Окончил пехотное училище.

Участник войны с января 1942 г. Воевал на Юго-Западном и Северо-Кавказском фронтах. Был тяжело ранен в сентябре 1942 г.

В декабре 1943 г. был переведен на 1-й Украинский фронт, назначен командиром 3-го батальона 838-го стрелкового полка 237-й стрелковой дивизии (с августа 1944 г. дивизия сражалась в составе 4-го Украинского фронта). За многократные отличия награжден орденами Отечественной войны 2-й степени, Александра Невского (приказ 1-й гв. армии № 46/н от 14 августа 1944 г.) [ЦАМО. Ф. 33. Оп. 690155. Д. 5901. Л. 7878об.], Богдана Хмельницкого 3-й степ. (приказ № 111/н 4-го Украинского фронта) [ЦАМО. Ф. 33. Оп. 690306. Д. 3112. Л. 1212об.].

Наминов Басан Басхаевич (1918-??). Калмык.

Уроженец хотона Чапчалган Хошеутовского улуса Калмыцкой степи.

Призван в январе 1942 г. Приволжским РВК Калмыцкой АССР.

Участник войны с 5 апреля 1942 г.
Вскоре после призыва направлен в Астраханское пехотное училище, которое в августе 1942 г. было преобразовано в 899-й стрелковый полк 248-й стрелковой дивизии 28-й армии. Полк защищал его родные места, степи Калмыкии. Затем он участвовал в боях на Миус-фронте и за Мелитополь, за отличия был представлен к ордену, но представление не было реализовано [Агарков 1982: 43]. 26 октября 1943 г. был ранен.

После излечения произведен в младшие лейтенанты и назначен командиром взвода 503-го стрелкового полка 91-й стрелковой дивизии 51-й армии 4-го Украинского фронта. Участвовал в боях в Крыму и под Севастополем, в одном из них заменил в бою погибшего командира роты, произведен в лейтенанты. В июне 1944 г. 51-ю армию передали в состав 1-го Прибалтийского фронта и перебросили в Латвию, где она сражалась под Шауляем, Паневежисом, Митавой. Награжден орденами Красной Звезды и Александра Невского (приказ № 111/н 51-й армии от 27 августа 1944 г.) [ЦАМО. Ф. 33. Оп. 687572. Д. 1729. Л. 277-277об.]. Произведен в капитаны.

После демобилизации был направлен на спецпоселение в Сибирь. После возвращения из депортации жил в г. Элисте.

Панченко Михаил Васильевич (1919??). Русский.

Призван в 1939 г. Элистинским ГВК Калмыцкой АССР.

Участник войны с октября 1942 г. Воевал на 4-м Украинском, 3-м Прибалтийском, Ленинградском фронтах. С апреля 1944 г. адъютант командарма-67 и 19 В. 3. Романовского. Награжден орденами Отечественной войны 1-й степени, Красного Знамени, Александра Невского (приказ № 0175 19-й армии от 17 апреля 1945 г.) [ЦАМО. Ф. 33. Оп. 686196. Д. 1640. Л. 20-20об.].

Потапов Андрей Кириллович (1912??). Русский.

Уроженец с. Яшкуль Икицохуровского улуса Калмыцкой степи.

Призван в 1941 г. Черноземельским РВК Калмыцкой АССР. Окончил военное училище.

Участник войны с сентября 1942 г. Воевал на Донском, Брянском, Белорусском и 1-м Украинском фронтах. Участник Сталинградской битвы, в ходе которой командовал взводом роты ПТР 135-го отд. истребительно-противотанкового дивизиона 273-й стрелковой дивизии. Осенью 1944 г. 
был назначен командиром огневого взвода того же дивизиона. Отличился в боях в Польше и Силезии, при форсировании Вислы и штурме Бреслау. Награжден медалью «За отвагу», орденами Отечественной войны 2 и 1-й степеней, Александра Невского (приказ № 010/н командующего артиллерией 6-й армии от 28 марта 1945 г.) [ЦАМО. Ф. 33. Оп. 690306. Д. 1659. Л. 68-68об.].

Пэрн Лембит Абрамович (1903-1974). Эстонец.

Уроженец с. Эсто-Хагинка Медвеженского уезда Ставропольской губернии (к 1941 г. Эсто-Хагинка входила в состав Яшалтинского улуса Калмыцкой АССР, ныне с. Яшалта Республики Калмыкия).

Окончил трехлетнюю школу и поступил в гимназию. После закрытия гимназии вернулся в родное село, стал работать продавцом в сельском потребительском обществе, а в 16 лет стал школьным учителем, инструктором по борьбе с неграмотностью среди взрослых. В 1920 г. юный Лембит был избран секретарем волостного ревкома, а в 1921 г. назначен зам. командира отряда по борьбе с бандитизмом.

В 1922 г. Большедербетовский улусный райком ВКП(б) направил Л. А. Пэрна в 3-ю объединенную Интернациональную военную школу.

После окончания школы в 1924 г. был командиром взвода, роты, зам. начальника штаба полка и дивизии, награжден орденом «Знак Почета». Окончил две военные академии: им. М. В. Фрунзе и Генерального штаба. После окончания последней был оставлен старшим преподавателем на кафедре тактики высших соединений, присвоено звание доцента. В 1939 г. полковник Пэрн защитил диссертацию и стал первым эстонцем - кандидатом военных наук. После присоединения Эстонии был назначен зам. начальника штаба 8-й армии, затем начальником штаба 2-го стрелкового корпуса, с которым встретил начало войны.

В августе 1941 г. был назначен начальником штаба 50-й армии, оказался в окружении, затем руководил оперативной группой Генштаба на Западном фронте, после этого служил начальником штаба 59-й армии. Трижды ранен. Участник Битвы за Москву. Награжден орденом Красного Знамени, присвоено звание генерал-майора.

В апреле 1942 г. был назначен командиром 249-й Эстонской стрелковой дивизии, в июне - командиром 7-й Эстонской стрелковой дивизией. В августе 1942 г. обе дивизии были сведены в 8-й Эстонский стрелковый корпус, которым с начала формирования и до конца войны руководил генерал-майор (с сентября 1943 г. - генерал-лейтенант) Л. А. Пэрн. Сражался в составе Калининского, 2-го Прибалтийского и Ленинградского фронтов, участвовал в сражении под Великими Луками, в освобождении Прибалтики [Великая Отечественная 2014: 149-150]. За освобождение материковой Эстонии награжден орденом Кутузова 1-й степени [ЦАМО. Ф. 33. Оп. 686043. Д. 103. Л. 122], за освобождение острова Сааремаа - орденом Суворова 2-й степени [ЦАМО. Ф. 33. Оп. 686046. Д. 163. Л. 179179об.].

После войны был наркомом (министром) обороны Эстонской ССР, преподавал в Военной академии Генштаба. Уволен в запас в 1965 г. Проживал в г. Москве.

Санджиров Николай Мартынович (1921-1944). Калмык.

Уроженец с. Цаган-Нур Малодербетовского улуса Калмыцкой степи. В начале 1930-х гг. вместе с семьей переехал в с. Садки (ныне Дубовский район Волгоградской области), где учился в начальной школе. После этого он окончил семилетнюю школу и педагогическое училище в Дубовке. Из училища был выпущен буквально накануне войны

15 июля 1941 г. призван Дубовским РВК Сталинградской области, который направил перспективного и образованного паренька в Черниговское военно-инженерное училище, эвакуированное в Иркутск [Трембач 1963: 79]. Н. М. Санджиров закончил его в феврале 1942 г. и получил назначение на фронт.

В мае 1942 г. он был назначен командиром взвода 91-го инженерно-саперного батальона 47-й армии Северо-Кавказского, затем Закавказского фронта. Участвовал в боях за Новороссийск (награжден орденом Красной Звезды), на Курской дуге, по освобождению Левобережной Украины и форсирования Днепра. За бои на букринском плацдарме Санджирову присвоили звание Героя Советского Союза с вручением ордена Ленина [Юшкова 1975: 199-202].

В июне 1944 г. 91-й инженерно-саперный батальон был включен в состав вновь сформированной 36-й инженерно-саперной бригады 28-й армии 1-го Белорусского фронта. Н. М. Санджиров был назначен ко- 
мандиром отдельной моторизованной роты инженерной разведки. За отличия в ходе операции «Багратион» награжден орденом Александра Невского (приказ № 34/н 28-й армии от 14 июля 1944 г.) [ЦАМО. Ф. 33. Оп. 690155. Д. 1411. Л. 53-53об.].

Старший лейтенант Н. М. Санджиров умер от ран 18 августа 1944 г. в г. Седльце Мазовецкого воеводства, где и был захоронен [ОБД «Мемориал»].

Семеняченко Александр Архипович (1918-??). Русский.

Уроженец с. Лагань Яндыко-Мочажного улуса Калмыцкой степи.

Призван 2 октября 1938 г. Долбанским РВК Калмыцкой АССР.

Участник войны с февраля 1944 г. на 2-м и 3-м Белорусских фронтах. Командир стрелковой роты 787-го стрелкового полка 222-й стрелковой дивизии 33-й армии 3-го Белорусского фронта, затем 52-го гв. стрелкового полка 17-й гв. стрелковой дивизии 5-го гв. стрелкового корпуса 39-й армии 3-го Белорусского и 1-го Прибалтийского фронтов. Трижды ранен. Награжден орденами Александра Невского (приказ № 0286 33-й армии от 20 июля 1944 г.) [ЦАМО. Ф. 33. ОП. 686196. Д. 1900. Л. 9-9об.] и Отечественной войны 1-й степени. Инвалид войны [ЦАМО. Ф. 33. Оп. 686196. Д. 1900. Л. 9-9об.].

После демобилизации жил в станице Курганной (с 1961 г. - г. Курганинск) Краснодарского края.

Сербин Андрей Петрович (1903-??). Молдаванин.

В документах указано, что он являлся уроженцем с. Гейдер Котовского района Одесской области, но найти это село на старых картах Одесской губернии пока не удалось.

Время и место первого призыва в Красную армию также установить не удалось. Известно, что А. П. Сербин в 24 года стал коммунистом, а в 1930-е гг. являлся кадровым военным, артиллеристом. В августе 1939 г. - феврале 1940 г. был командиром батареи 202-го отд. противотанкового дивизиона 124-й стрелковой дивизии, с которой участвовал в походе в Западную Украину, а потом в «финской» кампании. В период с февраля по сентябрь 1940 г. был командиром 202-го дивизиона. Затем его, по всей видимости, уволили в запас.

Повторно он был призван Западным РВК Калмыцкой АССР в марте 1942 г. и сразу назначен зам. командира 368-го истребительно-противотанкового дивизиона 280-й стрелковой дивизии. Позже капитан Сербин стал командиром этого дивизиона.

Участник войны с марта 1942 г. Сражался на Брянском, Центральном, Воронежском и 1-м Украинском фронтах. Участник боев на Курской дуге, форсирования Днепра, Львовско-Сандомирской и Висло-Одерской операций. Ранен.

За свои отличия награжден орденами Александра Невского (приказ № 0144/н 70-й армии от 27 августа 1943 г.) [ЦАМО. Ф. 33. Оп. 686044. Д. 75. Л. 265-265об.], Отечественной войны 2 и 1-й степеней, Красного Знамени. Любопытно отметить, что при прохождении последнего наградного листа командующий артиллерией 13-й армии генерал-лейтенант Д. Д. Кубеев предлагал присвоить майору А. П. Сербину звание Героя Советского Союза, но командарм-13 Н. И. Пухов не поддержал его [ЦАМО. Ф. 33. ОП. 690155. Д. 6316. Л. 334-334об.].

\section{Субботин Анатолий Михайлович} (1922-2012). Русский.

Уроженец с. Песчаное Манычского улуса Калмыцкой автономной области.

Призван в марте 1941 г. Черноземельским РВК Калмыцкой АССР.

Участник войны с июня 1942 г. на Ленинградском фронте. В сентябре был ранен. После излечения был направлен в минометное училище. С октября 1943 г. воевал на 2, 3 и 1-м Украинских фронтах. Командир минометной роты 173-го гв. стрелкового полка 58-й гв. стрелковой дивизии, в котором сражался до конца войны. За боевые отличия награжден орденами Отечественной войны 2-й степени, Александра Невского (приказ № 34/н 5-й гв. армии от 27 апреля 1945 г.) [ЦАМО. Ф.33. Оп. 690306. Д. 2082. Л. 45-45об.], Отечественной войны 1-й степени [ЦАМО. Ф. 33. Оп. 690306. Д. 1091. Л. 70-70об.]. Окончил войну в Праге.

После демобилизации жил в с. Яшкуль Калмыцкой АССР.

Фролов Василий Иванович (1916-??). Русский.

Уроженец хутора 1-я Березовка Хоперского округа Области Войска Донского (в 1941 г. село входило в состав Бударинского района Сталинградской области).

Призван в ноябре 1937 г. Сарпинским РВК Калмыцкой АССР.

Участник войны с июня 1941 г. Окончил артиллерийское училище. 
С сентября 1943 г. командир 5-й батареи 56-й пушечной артиллерийской бригады 26-й артиллерийской дивизии РГК, которая последовательно входила в состав 4-го Украинского, затем 1 и 2-го Белорусского фронтов. Участвовал в боях по освобождению Крыма, Белоруссии, Польши. Награжден орденами Красной Звезды и Александра Невского (приказ № 013/н командующего артиллерией 2-го Белорусского фронта от 13 марта 1945 г.) [ЦАМО. Ф. 33. Оп. 686196. Д. 1781. Л. 34-34об.].

Халявкин Есин Эмгенович (19181944). Калмык.

Уроженец с. Ахнуд Большедербетовского улуса. Окончил Башантинский техникум.

Призван Западным РВК Калмыцкой АCCР в 1938 г.

Участник боевых действий с октября 1941 г. на Юго-Западном фронте. Дважды ранен (в декабре 1941 г. и феврале 1942 г.).

Окончил курсы младших лейтенантов, и в сентябре 1942 г. был назначен командиром взвода автоматчиков мотострелково-пулеметного батальона 6-й гв. танковой бригады, сражавшейся под Сталинградом, а с ноября - в Калмыкии.

Весной 1943 г. в звании гв. старшего лейтенанта был направлен в 3-ю резервную армию командиром взвода, затем командиром роты автоматчиков 23-го стрелкового полка вновь сформированной 51-й стрелковой дивизии, с которой он прошел боевой путь почти до самой смерти. Сражался в составе Западного, 1 и 2-го Прибалтийских фронтов. Произведен в капитаны. Награжден медалью «За боевые заслуги», орденами Красного Знамени, Красной Звезды, Александра Невского (приказ № 0216 4-й ударной армии от 4 мая 1944 г.) [ЦАМО. Ф. 33. Оп. 690155. Д. 3472. Л. 132-132об.], Отечественной войны 2-й степени [ЦАМО. Ф. 33. Оп. 690155. Д. 3545. Л. 174-174об.].

3 июля 1944 г. гвардии капитан Е. Э. Халявкин был ранен в 3-й раз. После излечения он был направлен не в родную 51-ю, а в 239-ю стрелковую дивизию. 9 августа был ранен в 4-й раз, а 15 августа умер от сепсиса и истощения в 71-м местном эвакуационном пункте 1-го Прибалтийского фронта и захоронен в могиле № 5 на кладбище в 7 км к северо-западу от г. Городок [ОБД «Мемориал»].

Чванов Иван Игнатьевич (1919-??). Украинец.

Уроженец с. Садовое Черноярского уезда Астраханской губернии (в 1941 г. это село входило в состав Сарпинского улуса Калмыцкой АССР).

Призван в 1939 г. Сарпинским РВК Калмыцкой АССР.

Участник войны с 25 июня 1941 г. Трижды ранен. В 1944 г. был командиром 5-й роты 38-го стрелкового полка 65-й стрелковой дивизии 99-го стрелкового корпуса 14-й армии Карельского фронта, которая сражалась против егерей 20-й горной армии вермахта. За отличие при форсировании реки Титовка награжден орденом Александра Невского (приказ № 287 14-й армии от 4 ноября 1944 г.) [ЦАМО. Ф. 33. Оп. 690155. Д. 7113. Л. 58-58об.].

После демобилизации жил в с. Садовое Сарпинского района Калмыцкой АССР.

Чернобров Максим Ефимович (1913??). Украинец.

Уроженец с. Антоновка Васильковского уезда Киевской губернии (в 1941 г. это село входило в состав Узинского района Киевской области).

Служил в Красной армии в 1936-1938 гг.

Повторно призван Западным РВК Калмыцкой АССР в марте 1942 г.

Участник войны с августа 1942 г. Воевал на Брянском, Центральном, Белорусском и 1-м Белорусском фронтах. Трижды ранен. Замполит командира стрелкового батальона 539-го стрелкового полка 108-й стрелковой дивизии 50-й армии Брянского фронта, затем парторг, замполит командира дивизиона 124-го минометного полка 1-й минометной бригады 5-й артиллерийской дивизии РГК 1-го Белорусского фронта. Награжден орденами Александра Невского (приказ № 293 50-й армии от 11 октября 1943 г.) [ЦАМО. Ф. 33. Оп. 682526. Д. 1384. Л. 227-227об.], Отечественной войны 2 и 1-й степеней, Красной Звезды [ЦАМО. Ф. 33. Оп. 686196. Д. 2896. Л. 383-383об.].

После демобилизации жил в с. Иванковичи Васильковского района Киевской области Украины.

Шамолдаев Бавур Шамолдаевич (1904-1988). Калмык.

Уроженец Бага-Чоносовского аймака Манычского улуса. Окончил рабфак в Саратове, и был направлен секретарем парторганизации в колхоз «III Интернационал» Западного улуса, затем работал инструктором райкома ВКП (б) в Башанте.

Призван в декабре 1941 г. Западным РВК как политработник. 
Участник войны с июня 1942 г. на ЮгоЗападном фронте. Ранен (август 1942 г.). В июне 1943 г. был направлен на переобучение.

В марте 1945 г. был назначен командиром взвода 415-го стрелкового полка 1-й стрелковой дивизии 114-го стрелкового корпуса 70-й армии 2-го Белорусского фронта. За отличие в ходе Штеттинско-Ростокской операции был награжден орденом Александра Невского (приказ № 210/н 70-й армии от 21 мая 1945 г.). Любопытно, что начдив и комкор пытались «повысить» представление до ордена Богдана Хмельницкого 3-й степ., но командующий 70-й армией генерал-полковник В. С. Попов «понизил» награду до ордена Александра Невского [ЦАМО. Ф. 33. Оп. 687572. Д. 1729. Л. 33-33об.].

После демобилизации в ноябре 1945 г. был направлен на спецпоселение в Омскую область. После возвращения из депортации жил в г. Элисте [Бакуева 2005].

Шарапов Маркел Санжинович (19071969). Калмык.

Уроженец Власовской станицы Сальского округа Области Войска Донского.

Призван Зимовниковским РВК Ростовской области в 1929 г., служил в Калмыцком эскадроне 5-й Блиновской кавалерийской дивизии. Через год его направили в Новочеркасскую кавалерийскую школу. После окончания школы М. С. Шарапов вернулся в Калмыцкий эскадрон, в котором командовал взводом, затем стал командиром эскадрона. В 1939 г. окончил годичные курсы Высшей школы штабных работников. В должности помощника начальника штаба 96-го кавалерийского полка 5-й Блиновской дивизии участвовал в походе в Западную Украину. В конце 1939 г. - начале 1940 г. участвовал в советско-финской войне в должности помощника начальника оперативного отдела штаба 9-й армии [Шарапов 1966: 7]. Весной 1940 г. его направили преподавателем в Львовское пехотное училище [Трембач 1963: 138-139].

В июле 1941 г. М. С. Шарапов был назначен командиром формируемого 202-го кавалерийского полка 74-й кавалерийской дивизии, во главе с которым уже в конце августа выступил на фронт [Шарапов 1966: 8]. Участник Битвы за Москву. В 1942 г. был командиром 293-го Башантинского кавалерийского полка 111-й Калмыцкой кавдивизии, затем 311-го Приволжского кавалерийского полка 110-й Калмыцкой кавдивизии. В начале 1943 г. подполковник М. С. Шарапов служил преподавателем тактики на курсах Западного фронта, но уже в марте добился назначения командиром 680-го стрелкового полка 169-й стрелковой дивизии, вместе с которым многократно отличился в боях на Брянском и 1-м Белорусском фронтах.

В ноябре 1944 г. полковник М. С. Шарапов принял командование 751-м стрелковым полком 165-й стрелковой дивизии, с которым сражался на 2-м Белорусском фронте. Ранен. За многократные отличия при освобождении Белоруссии и Польши был награжден орденами Красного Знамени, Суворова 3-й степени [ЦАМО. Ф. 33. Оп. 686044. Д. 4490. Л. 237-237об.], Кутузова 3-й степени [ЦАМО. Ф. 33. Оп. 686196. Д. 4066. Л. 338-338об.], Красной Звезды (за выслугу 15 лет службы).

После восстановления автономии Калмыкии жил в г. Элисте.

Щербань Алексей Иванович (1919??). Украинец.

Уроженец с. Щербаки Машевского района Полтавской губернии Украины.

Призван Западным РВК Калмыцкой АССР 12 января 1942 г.

Участник войны с июня 1942 г. на Донском и Сталинградском фронтах. Окончил пехотное училище.

С сентября 1944 г. младший лейтенант А. И. Щербань сражался на 2-м Белорусском фронте, как командир стрелкового взвода 563-го стрелкового полка 153-й стрелковой дивизии. За отличия в боях награжден орденами Александра Невского (приказ № 0478 50-й армии от 21 ноября 1944 г.) [ЦАМО. Ф. 33. Оп. 690155. Д. 3485. Л. 60-60об.] и Отечественной войны 2-й степени [ЦАМО. Ф. 33. Оп. 686196. Д. 1779. Л. 81-81об.].

После демобилизации жил в с. Беленькое Запорожского района Запорожской области Украины.

В работе Н. Ц. Манджиева «Достоин награждения» в числе жителей Калмыкии - кавалеров ордена Александра Невского указаны также капитан М. И. Берщацкий, майор В. А. Миллер, старший лейтенант Б. М. Хейчиев и с некоторой долей вероятности кумык А. М. Монтаев [Манджиев 2015: 305]. Однако анализ наградных документов Героя Советского Союза Б. М. Хечеева и представлявшегося к этому званию уроженца Эсто-Хагинки В. А. Миллера не выявил у них наличия «полководческих» 
орденов. Что касается кавалера ордена Александра Невского М. И. Бершацкого, то в карточке награжденного и во всех наградных листах местом рождения указан Зыряновский рудник Восточно-Казахстанской области, а местом призыва - Зыряновский РВК той же области.

Статистический анализ военных биографий 35 жителей Калмыкии, награжденных 40 «полководческими» орденами, позволил сделать определенные обобщения.

Большинство изучаемых персоналий это молодежь 1912-1925 гг. рождения, выросшая при Советской власти и воспитанная в духе преданности ее идеалам. Только 7 человек из 35 старше этого возраста, причем ненамного (от 31 до 38 лет на начало Великой Отечественной войны). Шестеро из семи «стариков» осознанно связали свое будущее с Советской властью и являлись ее активными сторонниками: четверо были кадровыми военными (Б. Б. Городовиков, Л. А. Пэрн, А. П. Сербин и М. С. Шарапов), один являлся профессиональным партработником - инструктором райкома партии (Б. Ш. Шамолдаев), еще один, защищая Родину, проявил такое мужество и способности, что был произведен в офицеры на поле боя (Н. Д. Бевеликов).

В разрезе национальностей эти 35 кавалера «полководческих» орденов представляют 5 этносов: 18 русских, 12 калмыков, 3 украинца, 1 эстонец, 1 молдаванин. При этом следует учесть, что после депортации всего калмыцкого народа в Сибирь командование к калмыкам-офицерам относилась с определенным недоверием, часть офицеров были фактически сняты с фронта и отправлены на службу во внутренние округа, что ограничивало их возможности для получения почетных наград. Например, в 1944 г. полковника В. А. Хомутникова представляли к ордену Суворова 3-й степени, однако награду сначала «понизили» до ордена Богдана Хмельницкого 2-й степени, а потом и вовсе приостановили. Лишь спустя три месяца после гибели В. А. Хомутникова этот наградной был реализован орденом Отечественной войны 1-й степени [ЦАМО. Ф. 33. Оп. 690306. Д. 892. Л. 418-418об.]. К ордену Богдана Хмельницкого 3-й степени представлялся и лейтенант Н. И. Эрдниев, но наградной лист постепенно «понизили» до медали [ЦАМО. Ф. 33. Оп. 686044. Д. 542. Л. 72-72об.]. Примеры «понижений» наградных мы приводили выше (у А. Б. Бутцинова, Д. Я. Надиева, Б. Ш. Шамолдаева и др.).
Думается, отнюдь неслучаен тот факт, что из 10 калмыков-кавалеров «полководческих» орденов, отмеченных этими наградами после начала депортации калмыцкого народа, половина (Т. П. Манджиев, Д. Я. Надиев, Н. М. Санджиров, Е. Э. Халявкин, М. С. Шарапов) получили эти награды в составе 1 и 2-го Белорусских фронтов, когда ими командовал К. К. Рокоссовский. Знаменитый полководец, уже испытавший на себе тяжесть «сталинского правосудия», не верил в огульные обвинения всех калмыков в коллаборационизме и, видимо, сочувственно относился к ним. Много лет у Рокоссовского адъютантом служил калмык И. Н. Жигреев. По воспоминаниям М. Т. Бимбаева именно Константин Константинович помог ему вернуться на фронт [Бимбаев 1983: 80].

Более двух третей изучаемых персоналий (все кавалеры орденов Богдана Хмельницкого и Александра Невского) были мобилизованы в первые два года войны, только десятерых призвали до войны. Почти все они имели военное профессиональное образование (впрочем, большинство из них получило ускоренное образование военного времени), кроме Н. Д. Бевеликова и Б. Б. Наминова, ставших офицерами на поле боя, а также старших сержантов В. И. Жукова и М. М. Игнатова, рядового А. Я. Горлова. Абсолютное большинство из них являлись ветеранами первых полутора лет войны: 20 человек вступили в первый бой с фашистами в 1941 г., 12 - в 1942 г.

По занимаемым должностям (здесь и далее должности, место службы и звания указываются на момент награждения «полководческими» орденами, в случае, если награждался дважды, то по первому награждению) изучаемые персоналии распределились следующим образом: один был командиром корпуса, один - командиром дивизии, один - командиром полка, один - заместителем командира полка, трое - командирами батальонов, двое командирами артиллерийских дивизионов, восемь - командирами рот (в том числе один - командиром минометной роты, один - саперной, один - инженерной разведки), трое - командирами артиллерийских батарей, десять - командирами взводов (в том числе один командир взвода артиллерии, два - ПТР, один - пулеметного). Еще трое (офицерами не являвшиеся) были командирами орудия и пулеметно- 
го расчета, а также стрелком. Некое недоумение вызывает появление в этом списке адъютанта командарма (М. В. Панченко) и замполита командира батальона (М. Е. Чернобров). Конечно, и адъютант, и замполит могли отличиться особой храбростью, но награждение «полководческими» орденами подразумевает командирскую работу, чего в наградных листах этих двух офицеров мы так и не увидели.

По родам войск изучаемые персоналии разделились так (за вычетом адъютанта и замполита): 19 были из пехоты (включая командиров стрелковых дивизии и полка, которые на самом деле являлись выходцами из кавалерии), восемь - артиллеристами (включая одного минометчика и одного зенитчика), двое - саперами, двое - бронебойщиками, двое - пулеметчиками. При этом семеро служило на 1-м Украинском фронте, шестеро - на 2-м Белорусском, пятеро - на 1-м Белорусском, по трое на 3-м Белорусском и 4-м Украинском, по двое - на 1-м Прибалтийском и 3-м Украинском, еще по одному - на Карельском, Ленинградском, Брянском, Западном, Центральном, Юго-Западном и Южном фронтах. Преобладание кавалеров «полководческих» орденов на 1-м Украинском, 1 и 2-м Белорусском фронтах вполне объяснимо: в 1944-1945 гг. они находились на острие главных ударов и операций Красной армии и давали больше возможностей отличиться своим офицерам. К тому же эти три фронта были наиболее многочисленными. Что касается остальных фронтов, то некоторое недоумение вызывает отсутствие кавалеров «полководческих» орденов на 2-м Украинском фронте. Иные закономерности в распределении этих командиров по фронтам, кроме вышеупомянутых награждений калмыков под командованием К. К. Рокоссовского, выявить не удалось.

Весьма характерно, что почти все кавалеры «полководческих» орденов были также отмечены другими наградами. По количеству орденов, полученных за годы Великой Отечественной войны за конкретные боевые отличия (здесь не учитываются ордена за выслугу лет и медали, за исключением «Золотой Звезды» Героя Советского Союза), изучаемые персоналии распределились так: один человек получил 7 наград, два - по 5 наград, пять - по 4 награды, девять - по 3 награды, четырнадцать по 2 награды, лишь четыре человека име- ло по одному ордену («полководческому»). Весьма характерный штрих: из 24 жителей Калмыкии - Героев Советского Союза - лишь трое имели полководческие ордена (Б. Б. Городовиков, А. А. Лопатин, Н. М. Санджиров).

Если же обратиться к обобщениям в зависимости от награды, то мы видим, что четыре кавалера орденов Суворова и Кутузова - это профессиональные военные, добровольно избравшие военную стезю еще до начала войны. Нельзя сказать, что их карьера до войны была легкой и быстрой: например, Л. А. Пэрн после 17 лет службы офицером, окончания двух академий при наличии ордена, ученого звания и степени был полковником, Б. Б. Городовиков после 11 лет службы офицером (в том числе двух лет командования полком) и окончания двух академий (несмотря на родство с именитым дядей) - майором, а М. С. Шарапов после 9 лет службы офицером, окончания академии, похода в Западную Украину и «финской» кампании - капитаном. Своими наградами (3, 7 и 3 ордена соответственно) и чинами (генерал-лейтенанта, генерал-майора и полковника соответственно), полученными к концу войны, они были обязаны своим личным заслугам и знаниям военного искусства.

5 жителей Калмыкии - кавалеры ордена Богдана Хмельницкого являлись офицерами, сержантами, рядовым. Все пятеро были призваны во время войны. Однако сделать какие-то еще обобщения довольно трудно из-за их слишком малого количества.

Что касается 27 жителей Калмыкии кавалеров ордена Александра Невского, то видно, что большинство из них являлись классическими офицерами военного времени - низового эшелона командного состава передней линии фронта, вытянувшим «на своем горбу» всю Великую Отечественную войну 1941-1945 гг.

\section{ИСТОЧНИКИ / SOURCES}

Великая Отечественная 2014 - Великая Отечественная: Комдивы. Военный биографический словарь. Том V. Командиры стрелковых, горнострелковых крымских, полярных, петрозаводских дивизий, дивизий ребольского направления, истребительных дивизий (Пивоваров - Яцун). М.: Кучково поле, 2014. 1168 c. [Velikaya Otechestvennaya: Komdivy. Voennyy biograficheskiy slovar'. Tom 
V. Komandiry strelkovykh, gornostrelkovykh, krymskikh, polyarnykh, petrozavodskikh diviziy, diviziy rebol'skogo napravleniya, istrebitel'nykh diviziy (Pivovarov - Yatsun) [The Great Patriotic War: division commanders. A military biographical dictionary. Vol. 5. Commanders of rifle, mountain and moppingup divisions ... (names: Pivovarov to Yatsun)]. Moscow: Kuchkovo Pole, 2014. 1168 p. (In Rus.)]

Ведомости 1944 - Ведомости Верховного Совета СССР. 1944. 26 марта. № 17 (277). [Vedomosti Verkhovnogo Soveta SSSR (Bulletin of the Supreme Soviet of the Soviet Union). 1944. 26 March. No. 17 (277). (In Rus.)]

Всесоюзная перепись - Всесоюзная перепись населения 1939 года. Основные итоги сост. Ю. А. Поляков, В. Б. Жиромская, А. А. Исупов, И. Н. Киселев. М.: Наука, 1992. 256 c. [Vsesoyuznaya perepis' naseleniya 1939 goda. Osnovnye itogi [The 1939 All-Union Census: main results]. Yu. A. Polyakov, V. B. Zhiromskaya, A. A. Isupov, I. N. Kiselev (comp.). Moscow: Nauka, 1992. 256 p. (In Rus.)]

Герои 1987 - Герои Советского Союза: Краткий биографический словарь в 2 т. Т. 1. М.: Воениздат, 1987. 911 с. [Geroi Sovetskogo Soyuza [Heroes of the Soviet Union]. A brief biographical dictionary: in 2 vol. Vol. 1. Moscow: Voenizdat, 1987. 911 p. (In Rus.)]

Герои 1988 - Герои Советского Союза: Краткий биографический словарь в 2 т. Т. 2. М.: Воениздат, 1988. 863 с. [Geroi Sovetskogo Soyuza [Heroes of the Soviet Union]. A brief biographical dictionary: in 2 vol. Vol. 2. Moscow: Voenizdat, 1988. 863 p. (In Rus.)]

Кавалеры 2000а - Кавалеры ордена Александра Невского Москвы и Московской области. Т. 1. М.: Альтекс, 2000. 535 с. [Kavalery ordena Aleksandra Nevskogo Moskvy i Moskovskoy oblasti [Recipients of the Soviet Order of Alexander Nevsky: Moscow and Moscow Oblast]. Vol. 1. Moscow: Al'teks, 2000. 535 p. (In Rus.)]

Кавалеры 2000б - Кавалеры ордена Славы трех степеней: Краткий биографический словарь. М.: Воениздат, 2000. 703 с. [Kavalery ordena Slavy trekh stepeney [Recipients of the Order of Glory: three classes]. A brief biographical dictionary. Moscow: Voenizdat, 2000. 703 p. (In Rus.)]

Красная звезда 1968 - Красная звезда. 1968. 22 февраля. [Krasnaya zvezda (newspaper). 1968. 22 February. (In Rus.)]
ОБД «Мемориал» - Обобщенный банк данных (ранее - Объединенная база данных) «Мемориал» [электронный ресурс] // URL: https://obd-memorial.ru/html/ (дата обращения: 03.05.2016). [Obobschennyy bank dannykh (ranee - Ob"edinennaya baza dannykh) "Memorial» ['Memorial': a consolidated database]. An Internet resource: see hyperlink above (accessed: 3 May 2016). (In Rus.)]

ОБД «Подвиг народа» - Электронный банк документов «Подвиг народа в Великой Отечественной войне 1941-1945 гг.» [электронный ресурс] // URL: http://podvignaroda. $\mathrm{ru} /$ ?\#tab=navHome (дата обращения: 08.07.2018). [Elektronnyy bank dokumentov «Podvig naroda v Velikoy Otechestvennoy voyne 1941-1945 gg.» ['The Nation's Valour in the Great Patriotic War (1941- 1945)': an online database]. An Internet resource: see hyperlink above (accessed: 8 July 2018). (In Rus.)]

ПМА - Полевые материалы автора (ПМА): Пальтеева Серафима Эренценовна. [Polevye materialy avtora (PMA) [Author's field data]. Informant: Serafima E. Palteeva. (In Rus.)]

Сборник 1956 - Сборник законов СССР и указов Президиума Верховного Совета СССР (1938 г. - июль 1956 г.) / сост. М. И. Юмашев, Б. А. Жалейко. М.: Госюриздат, 1956. 500 c. [Sbornik zakonov SSSR $i$ ukazov Prezidiuma Verkhovnogo Soveta SSSR (1938 g. - iyul' 1956 g.) [Collected laws of the USSR and decrees issued by the Presidium of the Supreme Soviet of the Soviet Union: $1938-$ July 1956]. M. I. Yumashev, B. A. Zhaleyko (comp.). Moscow: Gosyurizdat, 1956. 500 p. (In Rus.)]

Солдаты Победы 2015 - Солдаты Победы. T. II. Поименный список воинов 110-й Отдельной Калмыцкой кавдивизии / сост. П. Э. Алексеева, А. Т. Баянова, С. А. Заярный, Л. Ю. Ланцанова. Изд. 2-е, перераб. и доп. Элиста: КИГИ РАН, 2015. 373 с. [Soldaty Pobedy. T. II. Poimennyy spisok voinov 110-y Otdel'noy Kalmytskoy kavdivizii [Soldiers of the Victory. Vol. 2. $110^{\text {th }}$ Separate Kalmyk Cavalry Division: a name list]. P. E. Alekseeva, A. T. Bayanova, S. A. Zayarnyy, L. Yu. Lantsanova (comp.). $2^{\text {nd }}$ ed., rev. and suppl. Elista: Kalmyk Humanities Research Institute, 2015. 373 p. (In Rus.)]

ЦАМО - Центральный архив министерства обороны РФ (ЦАМО). [Tsentral'nyy arkhiv ministerstva oborony RF (TSAMO) [Central Archives of the Ministry of Defense of the Russian Federation].] 


\section{ЛИТЕРАТУРА / REFERENCES}

Агарков 1982 - Агарков Б. Пути-дороги фронтовые: сб. очерков. Элиста: Калм. кн. изд-во, 1982. 89 с. [Agarkov В. Puti-dorogi frontovye [Paths and routes of war]. Coll. essays. Elista: Kalm. Book Publ., 1982. 89 p. (In Rus.)]

Бакуева 2005 - Бакуева E. С. Герой своего времени // Элистинская панорама. 2005. 24 марта. [Bakueva E. S. A hero of his time. Elistinskaya panorama (newspaper). 2005, 24 March. (In Rus.)]

Балакаев 1995 - Балакаев A. Г. Народный генерал: Политический роман-эссе. Элиста, РИП «Ботхн», 1995. 400 с. [Balakaev A. G. Narodnyy general [The people's general]. A political novel. Elista: Botkhn, 1995. 400 p. (In Rus.)]

Балакаева 2013 - Балакаева Н. Не дожил до ордена // Известия Калмыкии. 2013. 18 мая. C. 4. [Balakaeva N. Was never alive to see his well-deserved order. Izvestiya Kalmykii (newspaper). 2013, 18 May. P. 4. (In Rus.)]

Беляков, Надышев 2009 - Беляков B., Надышев Е. За отвагу и умелоекомандование // Элистинский курьер. 2009. 20 февраля. [Belyakov V., Nadyshev E. Rewarding his bravery and skilful command. Elistinskiy kur'er (newspaper). 2009, 20 February. (In Rus.)]

Бимбаев 1983 - Бимбаев М. Т. Судьба моя военная. Элиста: Калм. кн. изд-во, 1983. 156 c. [Bimbaev M. T. Sud'ba moya voennaya [My military destiny]. Elista: Kalm. Book Publ., 1983. 156 p. (In Rus.)]

Годаев 2005 - Годаев П. О. От Халхин-Гола до Кёнигсберга // Во имя безопасности России. Элиста: УФСБ РФ по РК, 2005. C. 81-87. [Godaev P. O. From Khalkhyn Gol to Königsberg. Vo imya bezopasnosti Rossii. Elista: Federal Security Service of Russia Kalmykia Office, 2005. Pp. 81-87. (In Rus.)]

Илишкин 2003 - Илишкин Н. «Порядочному человеку совестно даже перед собакой» // Известия Калмыкии. 2003. 22 января. [Ilishkin N. A decent person is he who feels ashamed even before a dog. Izvestiya Kalmykii. 2003, 22 January. (In Rus.)]

Каруева 2010 - Каруева И. За мужество, верность и преданность Родине // Хальмг
Үнн. 2010. 2 марта. [Karueva I. Rewarding his bravery, devotion and faithfulness to Motherland. Khal'mg ünn (newspaper). 2010, 2 March. (In Rus.)]

Князев $1975-$ Князев В. Один из одиннадцати // Теегин герл. 1975. № 2. С. 178-183. [Knyazev V. One of the eleven. Teegin gerl (journal). 1975. No. 2. Pp. 178-183. (In Rus.)]

Манджиев 2015 - Манджиев Н. Ц. Достоин награждения. М.: Принт Про, 2015. 498 с. [Mandzhiev N. Ts. Dostoin nagrazhdeniya [Deserves rewarding]. Moscow: Print Pro, 2015. 498 p. (In Rus.)]

Надиев 2003 - Надиев Д. Я. Жизнь многоликая. Элиста: Джангар, 2003. 181 c. [Nadiev D. Ya. Zhizn' mnogolikaya [The many-faced life]. Elista: Dzhangar, 2003. 181 p. (In Rus.)]

Очиров 2016а - Очиров У. Б. База данных калмыков - кавалеров ордена Славы: опыт составления и статистический анализ // Русская старина. 2016а. № 3(19). С. 218239. [Ochirov U. B. A database of Kalmyks rewarded the Order of Glory: a compilation effort and statistical analysis. Russkaya starina. 2016a. No. 3(19). Pp. 218-239. (In Rus.)]

Очиров 20166 - Очиров У. Б. Калмыки кавалеры ордена Александра Невского // Вестник Калмыцкого университета. 2016б. № 4. C. 29-39. [Ochirov U. B. Kalmyk Red Army officers - recipients of the Order of Alexander Nevsky. Vestnik Kalmytskogo universiteta. 2016b. No. 4. Pp. 29-39. (In Rus.)]

Трембач 1963 - Трембач И. С. Дорогой подвигов. Элиста: Калмгосиздат, 1963. 184 с. [Trembach I. S. Dorogoy podvigov [Following the path of valor]. Elista: Kalmgosizdat, 1963. 184 p. (In Rus.)]

Шарапов 1966 - Шарапов М. С. От Москвы до Берлина. Элиста: Калм. кн. изд-во, 1966. 72 c. [Sharapov M. S. Ot Moskvy do Berlina [From Moscow to Berlin]. Elista: Kalm. Book Publ., 1966. 72 p. (In Rus.)]

Юшкова 1975-Юшкова А. Он был коммунистом // Звезды над степью. Элиста: Калм. кн. издво, 1975. С. 194-205. [Yushkova A. He was a Communist. Zvezdy nad step'yu [Stars over the steppe]. Elista: Kalm. Book Publ., 1975. Pp. 194-205. (In Rus.)] 
UDC 94(47).084.8

\title{
Kalmykia's Residents - Recipients of 'Orders for Military Commanding Officers'
}

\author{
Utash B. Ochirov ${ }^{1}$
}

${ }^{1}$ Ph.D. in History (Doct. of Historical Sc), Chief Research Associate, Department of History, Ethnology and Archeology, Kalmyk Scientific Center of the RAS (8, I. K. Ilishkin Str., Elista, 358000, Russian Federation). ORCID: 0000-0001-9957-5215. E-mail: ochirovub@kigiran.com

\begin{abstract}
Introduction: The article analyzes military biographies of Kalmykia's residents - Kalmykiaborn individuals (within the boundaries of 1941), individuals who had arrived from other territories to be conscripted by the Red Army in the republic, and other alien-born citizens to have resided in Kalmykia after 1957 — who had received 'orders for commanding officers'. The latter include orders awarded to senior and middle-ranking officers for military commanding skills only, namely: Order of Suvorov, Order of Kutuzov, Order of Bogdan Khmeltitsky (the range of recipients being a little wider), and Order of Alexander Nevsky. The orders were established by the Soviet Government in 1942-1943 when it became evident that commanding skills of Red Army officers was far more important and significant than individual bravery or even political fanaticism.

During the Great Patriotic War, 35 residents of Kalmykia (including five ones awarded twice) received such military decorations: four Orders of Suvorov, three Orders of Kutuzov, five Orders of Bogdan Khmeltitsky, and twenty eight Orders of Alexander Nevsky. The paper contains concise military biographies of all the 35 cavaliers.

Goals: The paper aims to examine military biographies of Kalmykia's cavaliers of 'orders for red Army commanders' and reveal their somewhat distinct and common features.

Methods: The study applied both general scientific methods (typological classification, analysis and synthesis, induction and deduction, comparison and analogy) and those of special historical research (historical-genetic, historical-comparative, historical-typological, and historical-systematic methods).

Results: The statistical analysis revealed a number of distinct features inherent to this group of military commanders. For example, the majority of the investigated individuals (28 of 35) were young enough being aged 16 to 29 (at the outbreak of the war) to have been brought up during the Soviet era in strict adherence to Communist ideals and representations. The six older commanders (aged 31 to 38 respectively) were those to have voluntarily supported the Soviet regime, thus, being eager to defend it even at the expense of their lives. The bulk of the examined cavaliers were infantry officers, and included no representatives of technology-packed troops (fleet, air power, armored force, army signals). When viewed from a perspective of ethnic composition, only one third of the list is represented by ethnic Kalmyks, which evidently disagrees with the all-Union censuses according to which Kalmyks constituted a majority in the region. This had been largely contributed to by the unjust collaborationist accusations against the Kalmyks followed by a deportation of the whole nation to easternmost regions of the country.

Keywords: Great Patriotic War of 1941-1945, Kalmyk ASSR, Red Army, Order of Suvorov, Order of Kutuzov, Order of Bogdan Khmeltitsky, Order of Alexander Nevsky
\end{abstract}

